anorexia $(9 \%)$ e dois animais eram gonadectomizados $(9 \%)$. No exame fisico, onze cães exibiram catarata $(50 \%)$, onze apresentaram nódulos ou tumores mamários $(50 \%)$, dez animais estavam desidratados $(45.4 \%)$ e seis cães apresentaram disqueratoses $(27.2 \%)$. Em relação a urinálise, foi constatado que 18 cães tinham bacteriúria $(100 \%)$, onze exibiram cetonúria $(61.1 \%)$, dez demonstraram cristalúria $(55.5 \%)$ e oito cães tinham proteinúria $(44.4 \%)$. Na mensuração da bioquímica sérica, onze cães apresentaram hipercolesterolemia $(57.8 \%)$, oito animais demostraram aumento dos níveis séricos de transaminase pirúvica (ALT) e triglicerides $(42.1 \%)$ e dois cães tinham valores elevados de fosfatase alcalina $(10.25 \%)$. Através dos dados obtidos na população de animais estudada, foi possível concluir que a maioria dos cães diabéticos (mais de $50 \%$ deles), atendidos no Hovet-Unisa, era constituída por fêmeas, nào gonadectomizadas, com alterações clínicas representadas por emagrecimento, polidipsia, poliúria, polifagia, nódulos ou tumores mamários, e resultados de exames complementares caracterizados por hipercolesterolemia, bacteriúria cetonúria, e cristalúria. Estas observações visam auxiliar a conduta clínica quando do primeiro atendimento do cão diabético.

Bentubo, H'; Cardoso, T.G. '; Rocha, L.F.'; Bondan, E.F. ${ }^{1}$; Lallo, M.A. ${ }^{1}$

\section{4 - Estudo da longevidade de diferentes raças de cães na cidade de São Paulo}

1- Universidade Paulista (UNIP), São Paulo-SP

A idade é definida como um processo biológico complexo caracterizado pela redução da capacidade do indivíduo em manter a homeostasia, o que diminui sua viabilidade e aumenta a vulnerabilidade às doenças. Estudos revelam diferenças significantes na longevidade de cães de acordo com a raça, sendo que animais gigantes notadamente sobrevivem menos tempo que animais de raças pequenas. Outros fatores, tais como, genéticos, ambientais e nutricionais também se relacionam com o processo de envelhecimento. Faltam, no entanto, tais dados em relação à população canina no Brasil. O presente trabalho teve por objetivo avaliar a longevidade de cães de diversas raças na cidade de São Paulo, a fim de compreender suas relaçōes com alguns dos prováveis fatores de risco. Proprietários de cães já falecidos foram submetidos a um questionário com perguntas objetivas sobre idade de óbito dos animais, causa da morte, o sexo, a raça $\mathrm{e}$ a presença de outros fatores relacionados à sobrevida. Ao final da pesquisa, foram utilizadas as informações obtidas de 550 questionários, os quais foram compilados e analisados estatisticamente. A idade média geral de sobrevivência de todos os animais incluidos na pesquisa foi de 6 anos, tendo o animal mais velho morrido aos 22 anos. Animais sem raça definida apresentaram sobrevida média de 6 anos e 4 meses, enquanto que animais de raça definida viveram, em média, 5 anos e 8 meses. Em ordem decrescente de longevidade, as 10 raças mais prevalentes foram - Pequinês (11 anos, $\mathrm{n}=$ 13), Poodle ( 9 anos e 4 meses, $n=56$ ), Fox Paulistinha ( 9 anos e 2 meses, $n=19$ ), Dachshund ( 8 anos e 5 meses, $n=23$ ), Pastor Alemão ( 7 anos e 10 meses, $n=67$ ), Husky Siberiano ( 7 anos e 7 meses, $\mathrm{n}=11)$, Boxer $(7$ anos, $\mathrm{n}=11)$, Lhasa Apso (6 anos e 10 meses, $\mathrm{n}=23)$, Doberman ( 6 anos e 7 meses, $\mathrm{n}=11$ ) e Dog Alemão $(5$ anos e 7 meses, $\mathrm{n}$ =13). Com relação ao sexo, observou-se que as fêmeas viveram mais (média de 6 anos e 5 meses) que os machos (média de 5 anos e 5 meses). Animais castrados viveram em média mais tempo que os não castrados, sendo a sobrevida das fêmeas e machos castrados de, respectivamente, 11 anos e 5 meses e 8 anos e 9 meses. Os animais foram agrupados em 4

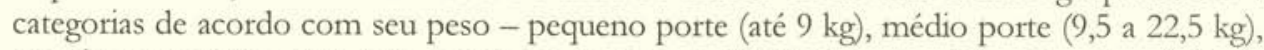
grande porte (23 a 40,5 kg) e gigantes (acima de 40,5 kg) e as médias de sobrevivência encontradas para cada classe foram, respectivamente, de 5 anos; 7 anos e 3 meses; 7 anos e 3 meses e 4 anos e 7 meses. De todos os animais investigados $10,72 \%$ morreram por causas naturais e $12,36 \%$ foram submetidos à eutanásia. Diferentes estados patológicos foram atribuídos à morte dos animais, sendo que as causas mais comumente observadas foram doenças infecciosas $(23,1 \%)$, traumas $(16,18 \%)$, neoplasias $(11,45 \%)$, intoxicações 
$(10,72 \%)$ e doenças metabólicas $(8,9 \%)$. A maior parte dos animais incluídos neste estudo vivia fora de casa $(62 \%)$, contudo, não houve diferença significante na sobrevida dos animais criados dentro e fora de casa. Por outro lado, animais considerados obesos pelos seus proprietários, viveram menos ( 5 anos e 7 meses) que os não obesos ( 8 anos e 9 meses). Os resultados deste trabalho permitem concluir que a longevidade média dos animais na cidade de São Paulo foi menor que a descrita para outros países. Animais sem raça definida viveram mais que animais com raça determinada, enquanto que animais castrados tiveram maior sobrevida que os não castrados. Entre os não castrados, as fêmeas tiveram maior longevidade que os machos e animais de pequeno porte e gigantes viveram por menos tempo que os de médio e grande porte.

\section{5 - Características clínico-epidemiológicas do hiperadrenocorticismo na região de Botucatu - SP}

Aptekmann, K.P.'; Peixoto, A.S.'; Altwegg, D.'; Vicente, P.C.'; Schwartz, D.S.2
1- Residente de Clínica Médica de Pequenos Animais da Faculdade de Medicina Veterinária e Zootecnia da Universidade Estadual Paulista, Campus de Botucatu, Botucatu-SP

2-Professora Assistente Doutora do Departamento de Clínica Veterinária da Faculdade de Medicina Veterinária e Zootecnia da Universidade Estadual Paulista, Campus de Botucatu, Botucatu-SP

O hiperadrenocorticismo (HAC) é um distúrbio associado ao excesso de glicocorticóides endógenos ou exógenos, sendo uma das endocrinopatias mais comuns em cães, raramente diagnosticado em gatos. O HAC espontâneo ocorre devido ao aumento da secreçào endógena de cortisol, podendo ser hipófise ou adrenal-dependente. Quando o HAC resulta de causas exógenas, é referido como iatrogênico. Este trabalho objetiva mostrar a prevalência da doença na região de Botucatu-SP, evidenciando os dados de resenha, exames laboratoriais e os principais sintomas apresentados. Foi feito um levantamento entre janeiro de 1998 a abril de 2003, no Hospital Veterinário da FMVZ - Unesp, no qual foram obtidos 15 animais, sendo todos cães, com testes endócrinos que confirmaram o diagnóstico. Entretanto, outros cães com suspeita da doença não foram incluídos neste estudo por falta de teste endócrino confirmatório. Quanto às raças, o Poodle $(33 \%)$ e os animais sem raça definida $(26 \%)$ foram os mais comuns. Outras raças acometidas foram Maltês, Boxer, Akita, Pinscher, Teckel e Fox Paulistinha. A idade variou entre 4 e 12 anos, com média de 8 anos, sendo que $53 \%$ eram fêmeas e $47 \%$ eram machos. Em ordem de maior ocorrência, os sinais clínicos foram poliúria, polidipsia, polifagia, distensão abdominal, cansaço fácil, apatia, alterações dermatológicas (rarefaçào pilosa, discromia, calcinose cutânea, mapeamento vascular, verrugosidades), ganho de peso, hepatomegalia, dispnéia, pele adelgaçada, anestro, dificuldade locomotora, anorexia e vômito. Os achados mais comuns no hemograma foram linfopenia, eosinopenia, neutrofilia e monocitose, compativel com um hemograma de estresse, comum nos cães que apresentam HAC. Apenas um animal apresentou leucopenia com anemia macrocítica hipocrômica, não estando relacionado com HAC. A contagem de plaquetas estava elevada em $26 \%$ dos animais e o restante apresentou valores normais. A urinálise revelou densidade isostenúrica em 8 animais e hipostenúrica em 2; a infecção do trato urinário esteve presente $\mathrm{em}$ todos os animais que realizaram urinálise. No bioquímico foi constatado um aumento das enzimas hepáticas (ALT, FA, GGT) em todos os animais avaliados. Foi verificado que 2 animais apresentavam hiperglicemia, glicosúria e cetonúria, caracterizando um quadro de diabetes mellitus associado. O perfil renal mostrou-se alterado somente em um animal. Três animais apresentaram valores de colesterol dentro dos limites de normalidade e 9 apresentaram um aumento do mesmo. O exame ultrassonográfico foi realizado $\mathrm{em} 7$ càes, o qual evidenciou aumento das adrenais bilateral $\mathrm{em}$ um caso e aumento unilateral em dois casos, além de degeneração gordurosa em todos os animais em que o exame foi realizado. Para o diagnóstico definitivo de hiperadrenocorticismo foi realizado o teste de supressào com dexametasona, sendo que 2 cães apresentaram teste sugestivo de $\mathrm{HAC}$ adrenal-dependente e o restante hipófise-dependente. Apenas em um animal não foi realizado 